CENTRE FOR ECONOMIC HISTORY

THE AUSTRALIAN NATIONAL UNIVERSITY

DISCUSSION PAPER SERIES

Australian

ه $\approx$ National

University

POPULATION, MIGRATION AND LABOUR SUPPLY: GREAT BRITAIN 1871-2011

\author{
TIMOTHY J. HATTON \\ THE AUSTRALIAN NATIONAL UNIVERSITY \\ UNIVERSITY OF ESSEX
}

DISCUSSION PAPER NO. 2012-4

JUNE 2012

THE AUSTRALIAN NATIONAL UNIVERSITY

ACTON ACT 0200 AUSTRALIA

T 61261253590

F 61261255124

E enquiries.eco@anu.edu.au

http://rse.anu.edu.au/CEH 


\title{
Population, Migration and Labour Supply: Great Britain 1871-2011
}

By

\author{
Timothy J Hatton
}

(Australian National University and University of Essex)

June 2012

\begin{abstract}
A country's most important asset is its people. This paper outlines the development of Britain's human resources since the middle of the nineteenth century. It focuses on four key elements. The first is the demographic transition-the processes through which birth rates and death rates fell, leading to a slowdown in population growth. The second is the geographical reallocation of population through migration. This includes emigration and immigration as well as migration within Britain. The third issue is labour supply: the proportion of the population participating in the labour market and the amount and type of labour supplied. Related to this, the last part of the chapter charts the growth in education and skills of the population and the labour force.
\end{abstract}

JEL Codes: J11, J12, J21, J 24

Acknowledgements. This is the preliminary version of a chapter for the third edition of the Cambridge Economic History of Modern Britain, edited by Roderick Floud, Paul Johnson and Jane Humphries. A shorter version will appear in the published volume. I am indebted to Bernard Harris for very helpful and detailed comments on an earlier draft. I am also grateful for guidance on official statistics from Matthew Ford and Brian Mustoe of the Office of National Statistics. 


\section{Introduction}

A country's most important asset is its people. This paper outlines the development of Britain's human resources since the middle of the nineteenth century. It focuses on four key elements. The first is the demographic transition-the processes through which birth rates and death rates fell, leading to a slowdown in population growth. The second is the geographical reallocation of population through migration. This includes emigration and immigration as well as migration within Britain. The third issue is labour supply: the proportion of the population participating in the labour market and the amount and type of labour supplied. Related to this, the last part of the chapter charts the growth in education and skills of the population and the labour force.

\section{Demographic growth}

Between 1851 and 2011 the population of Britain increased by a factor of three-from just over 20 million to sixty million (Table 1). This includes England, Wales and Scotland but not Northern Ireland or the Irish Republic. Population grew at a little over one percent per annum in the second half of the nineteenth century and then slowed down in the twentieth century, averaging less than half a percent per annum. These modest rates of population growth are comparable with most European countries but they are much lower than the growth rates experienced in much of the developing world. Long run population growth has often been characterised as a demographic transition. Before its onset birth and death rates are both high and so population grows slowly. Then the death rate begins to fall leading to faster population growth. In the third stage birth rates fall (often by more than death rates) leading to even lower population growth than before the transition. For Britain we see the latter part of this transition spread over a very long period.

As Table 1 shows, in 185145 percent of the population was under the age of 20, a proportion that is similar to many developing countries that are passing through the demographic transition. By the end of the century this proportion had fallen to less than a quarter. At the other end of the life cycle, the share of the population aged 60 and above increased from only 7 percent in 1851 to more than 20 percent by the end of the $20^{\text {th }}$ century. These figures are used in the last column to calculate the dependency ratio-the young and the old divided by those at prime working age, 20-59. Contrary to popular belief, there has been no increase in the overall dependency ratio, but rather a switch from young to old age dependency. But because the most of those over 60 live independently there is less within-household support. Thus average household size fell from 4.5 persons in 1901 to just 2.3 in 2001 (Holmans, 2000, p. 470). 
Table 1: The Population of Great Britain, 1841-2011

\begin{tabular}{|r|r|r|r|r|r|r|}
\hline Year & $\begin{array}{r}\text { Population } \\
\text { (millions) }\end{array}$ & $\begin{array}{l}\text { Population } \\
\text { growth } \\
\text { (\% p. a.) }\end{array}$ & $\begin{array}{l}\text { Percent of } \\
\text { population } \\
\text { aged 0-19 }\end{array}$ & $\begin{array}{l}\text { Percent of } \\
\text { population } \\
\text { aged 20-59 }\end{array}$ & $\begin{array}{r}\text { Percent of } \\
\text { population } \\
\text { aged 60+ }\end{array}$ & $\begin{array}{l}\text { Dependency } \\
\text { ratio }\end{array}$ \\
\hline 1841 & 18.53 & & 46.16 & 46.61 & 7.24 & 1.15 \\
\hline 1851 & 20.82 & 1.16 & 45.34 & 47.32 & 7.34 & 1.11 \\
\hline 1861 & 23.13 & 1.05 & 45.37 & 47.13 & 7.50 & 1.12 \\
\hline 1871 & 26.07 & 1.20 & 45.84 & 46.61 & 7.55 & 1.15 \\
\hline 1881 & 29.72 & 1.31 & 46.30 & 46.26 & 7.44 & 1.16 \\
\hline 1891 & 33.03 & 1.06 & 45.33 & 47.21 & 7.46 & 1.12 \\
\hline 1910 & 37.02 & 1.14 & 42.52 & 50.05 & 7.43 & 1.00 \\
\hline 1911 & 40.83 & 0.98 & 40.13 & 51.82 & 8.05 & 0.93 \\
\hline 1921 & 42.77 & 0.46 & 37.23 & 53.36 & 9.42 & 0.87 \\
\hline 1931 & 44.80 & 0.46 & 32.81 & 55.65 & 11.53 & 0.80 \\
\hline 1939 & 45.61 & 0.14 & 29.81 & 56.13 & 14.05 & 0.78 \\
\hline 1951 & 48.86 & 0.82 & 28.68 & 55.55 & 15.76 & 0.80 \\
\hline 1961 & 51.28 & 0.48 & 30.22 & 52.69 & 17.09 & 0.90 \\
\hline 1971 & 53.97 & 0.51 & 30.82 & 50.14 & 19.03 & 0.99 \\
\hline 1981 & 53.75 & -0.04 & 28.85 & 51.12 & 20.03 & 0.96 \\
\hline 1991 & 54.98 & 0.23 & 25.30 & 53.54 & 21.16 & 0.87 \\
\hline 2001 & 57.10 & 0.38 & 24.99 & 54.13 & 20.88 & 0.85 \\
\hline 2011 & 60.84 & 0.63 & 23.41 & 53.79 & 22.81 & 0.86 \\
\hline
\end{tabular}

Sources: 1811 to 1931 and 1951-1981: calculated from Mitchell (1988) pp. 15-19; 1939 from the National Register Table II; 1991-2011 from Annual Abstract of Statistics, 2010.

The Mortality Transition

The aging of the population observed in Table 1 is largely the result of declining death rates. As Table 2 shows death rates secularly declined for all age groups from the late nineteenth century right through until the present. The $U$ shape formed by the age specific mortality rates has become shallower as mortality at the extremes of age has declined. In 1870-2 the risk of death before reaching the age of five was higher than the risk of death in the age range 65-74. But childhood mortality fell earlier and more steeply than mortality rates in old age. This is largely due to the steep decline in infant mortality (0-1 in Table 2), which is calculated as the number of deaths of infants aged less than one year divided by total births. The infant mortality rate remained stubbornly high at about 150 per thousand until the turn of the twentieth century, after which it declined steeply. Among the elderly population the gains are somewhat more significant than they appear as the average age within the oldest category has increased. One implication of the enhanced probability of surviving each age period is that life expectancy has increased dramatically. Based on the mortality rates of 1870-2 life expectancy at birth was about 40 . Over the course of the twentieth century the 
expectation of life increased by 30 years--from 45 for boys and 49 for girls in 1901 to 75 for boys and 80 for girls in $2001 .{ }^{1}$ About one third of this gain was due to the fall in infant mortality.

Table 2: Age-Specific Death Rates per Thousand: Great Britain 1870-2 to 1990-2

\begin{tabular}{|r|r|r|r|r|r|r|r|}
\hline Age & $1870-2$ & $1890-2$ & $1911-12$ & $1930-2$ & $1950-2$ & $1970-2$ & $1990-2$ \\
\hline $0-1$ & 151.92 & 145.98 & 110.02 & 66.31 & 30.03 & 17.82 & 7.28 \\
\hline $0-4$ & 65.90 & 57.66 & 37.91 & 20.06 & 6.62 & 4.07 & 1.82 \\
\hline $5-9$ & 8.01 & 4.91 & 3.26 & 2.20 & 0.59 & 0.36 & 0.18 \\
\hline $10-14$ & 4.53 & 2.87 & 2.03 & 1.50 & 0.46 & 0.30 & 0.19 \\
\hline $15-19$ & 6.50 & 4.33 & 2.88 & 2.44 & 0.82 & 0.65 & 0.51 \\
\hline $20-24$ & 8.47 & 5.51 & 3.52 & 3.06 & 1.18 & 0.70 & 0.65 \\
\hline $25-34$ & 10.11 & 7.45 & 4.55 & 3.38 & 1.49 & 0.83 & 0.74 \\
\hline $35-44$ & 13.07 & 11.88 & 7.34 & 5.06 & 2.62 & 2.01 & 1.44 \\
\hline $45-54$ & 17.62 & 18.61 & 13.00 & 9.59 & 6.81 & 5.89 & 3.73 \\
\hline $55-64$ & 30.52 & 34.88 & 26.25 & 20.42 & 17.54 & 15.36 & 11.27 \\
\hline $65-74$ & 62.58 & 70.98 & 56.48 & 49.77 & 43.74 & 38.28 & 29.55 \\
\hline $75-84$ & 137.72 & 147.53 & 123.50 & 121.28 & 111.01 & 90.57 & 71.41 \\
\hline $85+$ & 290.02 & 295.56 & 248.06 & 260.08 & 255.32 & 207.10 & 174.39 \\
\hline
\end{tabular}

Sources: Number of deaths by age group from Annual Abstract of Statistics, 1957, Table 28 and 2008, Table 5.19; births from Annual Abstract of Statistics, 1957, Table 20 and 2008, Table 5.15. Population cohorts at census years from the sources listed in Table 1.

What were the causes of this remarkable increase in life expectancy? Before 1960 most important single cause was the reduction in deaths from infectious disease. In the late nineteenth century the leading killer diseases included diphtheria, pneumonia, scarlet fever, tuberculosis, typhus and typhoid. To explain the downward trend it is natural to look at improvements in medical knowledge and the growth of medical services. But in an important book Thomas McKeown (1976) argued that this accounts for little of the improvement in longevity because effective drug therapies did not become available to most people until the 1940s-long after the onset of declines in the diseases they were designed to combat. McKeown also argued that other public interventions such as sanitary reforms (which provided the cities with clean water for drinking and hygienic sewage disposal) made only a modest contribution. This was because deaths from airborne diseases (such as tuberculosis) fell much more than deaths from waterborne diseases (such as cholera). By a process of elimination McKeown concluded that, while there was some fall in the virulence of certain diseases (and some contribution of sanitary reforms), the most important single cause of the general improvement in health and longevity was the improvement in living standards, and especially better nutrition.

\footnotetext{
${ }^{1}$ These figures are based on survival probabilities for different age groups observed at a given point in time. If instead they were calculated by following a given cohort over time they would be five to ten years higher (see ONS, 2008, pp. 52-4.
} 
These conclusions have been contested ever since. ${ }^{2}$ It is clear that the miracle drugs of the twentieth had their major impact from the 1940s especially as such treatments were made more widely available after the creation of the National Health Service in 1948. Before then, only the timing of the reduction in diphtheria mortality from around the turn of the century seems be consistent with the advent of treatment by antitoxin. Scholars have debated the issue of whether waterborne diseases were in fact slower to decline and whether there might be a greater role for improvements in the sanitary infrastructure than McKeown thought (Szreter, 1988; Guha, 1994). The evidence suggests that that investment in public health infrastructure significantly reduced infant mortality from the end of the nineteenth century (Bell and Millward, 1998, p. 243; Floud et al., 2011, p. 174).

These developments were accompanied by growing public appreciation of the importance of nutrition and domestic hygiene, particularly for the health and growth of children (Mokyr, 2000; Baier 2008). This is reflected by the spread of clinics and health visitors, the establishment (in 1908) of the School Medical Service (Harris, 1995) as well as a variety of public information campaigns. Thus the effects of improved medical knowledge were indirect and were more preventative than curative; and they mainly affected infants and children. Improved conditions during childhood may also have led to greater health and vitality throughout the life cycle. In the 1930s it was noted that improvements in survival rates at each age went with cohorts and not with periods (Kermack et al., 1934). Analysis of individual-level data for children in the 1930s confirms that poor childhood conditions negatively affected health and longevity in later life (Frijters et al., 2010).

Infectious diseases were gradually replaced as the main cause of death by chronic conditions that mainly affect older people such as cardiovascular disease, respiratory disease, diabetes and various forms of cancer. Between the first and last decades of the twentieth century the percentage of deaths accounted for by cancer increased from less than 10 percent to more than a quarter. Cardiovascular diseases accounted for more than 40 percent by the end of the twentieth century (Fitzpatrick and Chandola 2000, p. 103-4). Improved treatments for degenerative diseases have meant that while death rates at more advanced ages have declined, the proportion living with chronic illness or disability has increased. As a result, years in good health have increased by less than total life expectancy. By 2007-9 a person reaching the age of 65 could expect to spend only 5560 percent of the remaining lifespan in good health (ONS, 2011; c.f. Floud et al. 2011, pp 192, 367).

The levels and trends in health and mortality mask substantial variations by social class. In 1910-12 mortality rates were 42 percent above average in the families of unskilled manual workers they were

\footnotetext{
${ }^{2}$ It is worth noting that much of the debate over the so-called McKeown thesis is about the underlying causes of the growth in population during the century before 1870, which according to McKeown was also due mainly to rising living standards.
} 
12 percent below average in managerial and professional families. Over the twentieth century this inequality increased (although the absolute gaps declined), despite universal health care, improvement in the urban environment and growing equality in other socioeconomic indicators (Fitzpatrick and Chandola, 2000, p. 101). A study of Whitehall civil servants found a distinct gradient in mortality by occupational grade for all the major causes of death (Van Rossum et al., 2000). Some of these differences are explained by risk factors such as smoking and diet as well as by individual traits that are correlated with occupational attainment. Differences in mortality and morbidity also vary by region, with higher incidence in north and Scotland (Hanlon et al., 2005).

\section{The Fertility Transition}

Since the middle of the nineteenth century there has been a substantial decline in fertility. Figure 1 shows that the annual number of births per 1000 women aged $15-44$ fell from 150 in the 1870 s to a low of 60 in the 1930s, with a modest revival in the 1950s and 1960s followed by a further decline. The same pattern is observed in the total fertility rate, which implies an average of more than 4.5 births per women in the 1970s falling briefly to below two in the 1930s. The gross reproduction rate indicates that from the 1920s onwards natural increase has fluctuated around the replacement level. The onset of fertility decline occurred a little later in other European countries and after 1950 it occurred in a wide range of developing countries where the declines have been steeper and over a shorter period.

Figure 1: Fertility Rates in England and Wales, 1851-55 to 2006-10

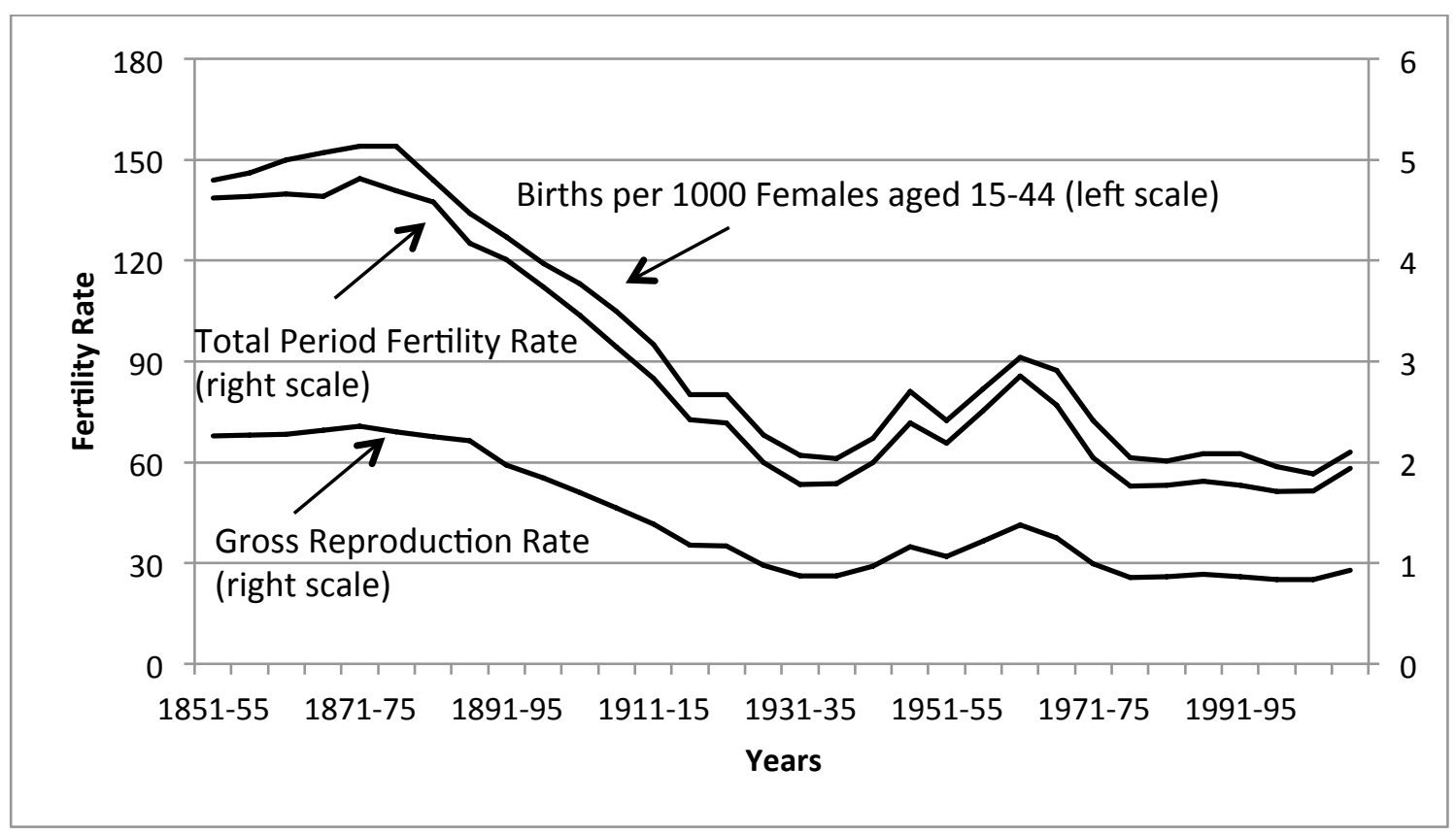

Sources: 1851-1950: OPCS (1987), Table 1.4, p. 26; 1951-2010: data kindly provided by ONS. 
Although fertility decline is broadly associated with economic development, its timing and causes are the subject of debate. Until the 1970s around 95 percent of births were within marriage. The marriage rate rose from 75 percent of women in their 30s in 1901 to 85 percent in 1931, and so this was not a cause of declining fertility. Rather it was control of fertility within marriage, principally by stopping childbearing earlier. Although family limitation was practised in the nineteenth century, access to contraception devices and better knowledge made this easier and more effective in the latter stages of the fertility decline (c.f. Szreter and Fisher, 2010, Ch. 6). The contraceptive pill, which became widely available in the 1960s, seems to have reduced unwanted pregnancies from the 1970s. Its introduction coincided with widening opportunities for women, a decline in the proportion married and a rise in cohabiting unions (Ermisch, 2008). Births outside marriage rose steeply after the 1960s to reach 40 percent of all births by 2000 .

It is sometimes argued that the initial decline in the birth rate is linked to the fall in the mortality rates of children and especially of infants (noted above). The idea is that a family needed fewer births to ensure that a sufficient number survived to adulthood--perhaps to provide for the parents in old age. But the fall in fertility preceded the sharp decline in infant mortality. It also fell by far more than would be necessary to replace expected child deaths and so the contribution of declining mortality can only have been marginal at best. Another argument is that the opportunity cost of children increased. One element is that opportunities for young children to contribute to family income declined, due to growing restrictions on child labour and advances in compulsory schooling. But again the effects on fertility were probably modest. Another is that growing opportunities for women to work led families to choose fewer children. Yet, as noted below, the labour market participation rate of women hardly increased until the 1950s. Before that women typically left the labour market on marriage and did not re-enter after childbearing. Thus while the costs of career interruption may have been a key consideration in recent decades it cannot have been an important factor in the original fertility decline.

It was widely noted among contemporaries that there were large differences in fertility by social class. Before the First World War households headed by professionals and salaried workers had an average of three children while those of labourers and other manual workers had nearly five. By the 1950s those differences had all but disappeared (Coleman and Salt, 1992, pp. 68, 162). It is often argued that fertility decline began among the upper and middle classes and then trickled down the scale of class and income in a gradual process of emulation. But this view has been qualified. In the nineteenth century there were sharp differences at similar status levels, for example between the large families of miners and the small families of textile workers. There were also distinct variations 
across localities that are not accounted for by class and occupation (Garrett et al., 2001). Nevertheless there is clear a correlation between higher social status or income and lower fertility (Barnes and Guinnane, 2011), which became weaker over time. One view is that this reflects the diffusion of middle class standards and aspirations, initially to better satisfy basic needs, and later to acquire consumer durables and owner occupied housing (Scott, 2008).

One key force for change is the shift in the aspirations of parents towards their children's futures rather than simply for their own comfort (Caldwell, 1980), something that is linked with the diffusion of basic education. It is suggested that parents chose fewer children in order to invest more in each child-trading off quantity for quality. These investments in the health and education of children take the form of parental time and financial resources. They are sometimes seen as enabling children to exploit growing returns to human capital, but the evidence for this is thin. ${ }^{3}$ While families may have chosen lower fertility for a variety of reasons, nevertheless the outcome was to give their children a better start in life. In the first half of the twentieth century children with fewer siblings were more likely to survive and to attain greater stature (Hatton and Martin, 2010). And evidence from the postwar period indicates that those in smaller families attained higher education levels, even allowing for other family circumstances (Booth and Kee, 2009; lacovou, 2008).

\section{Migration}

\section{International Migration}

Like other European countries Britain experienced a surge of emigration to the New World during the nineteenth century. Mass migration from the UK and Germany began in the middle of the decades of the century, a trend that was followed by the Scandinavian countries in the 1870s and 1880 s, and then from the 1890s, by the countries of southern and eastern Europe. These 'emigration transitions' were associated with demographic increase, with growing industrialisation and with rising living standards (Hatton and Williamson, 2005, Ch 2). Before this, a persistent trickle of emigrants left the UK as either as pioneering settlers, as indentured servants, or as convicts. This reflects the fact that intercontinental emigration involved significant costs and risks. In the 1840s emigrants were often farmers and artisans and their families aiming to settle at the frontiers of the New World. But as the costs and risks declined they were more often young, single unskilled workers

\footnotetext{
${ }^{3}$ This issue has been widely discussed in the economics literature. Some models (e.g. Galor and Weil, 1999) link fertility decline to the increase in demand for human capital associated with the industrial revolution. But the timing does not fit very well unless one assumes a lag of half a century or more.
} 
seeking employment in the booming urban centres. ${ }^{4}$ One important factor was the growing migrant stock in gateway cities and communities, which compounded the momentum of emigration flows. Previous emigrants helped to reduce the costs and the risks of emigration and this was reflected in distinctive channels of chain migration between specific localities in Britain and specific places in the destination countries.

Figure 2: Gross and Net Passenger Movement, UK Citizens 1853-1913

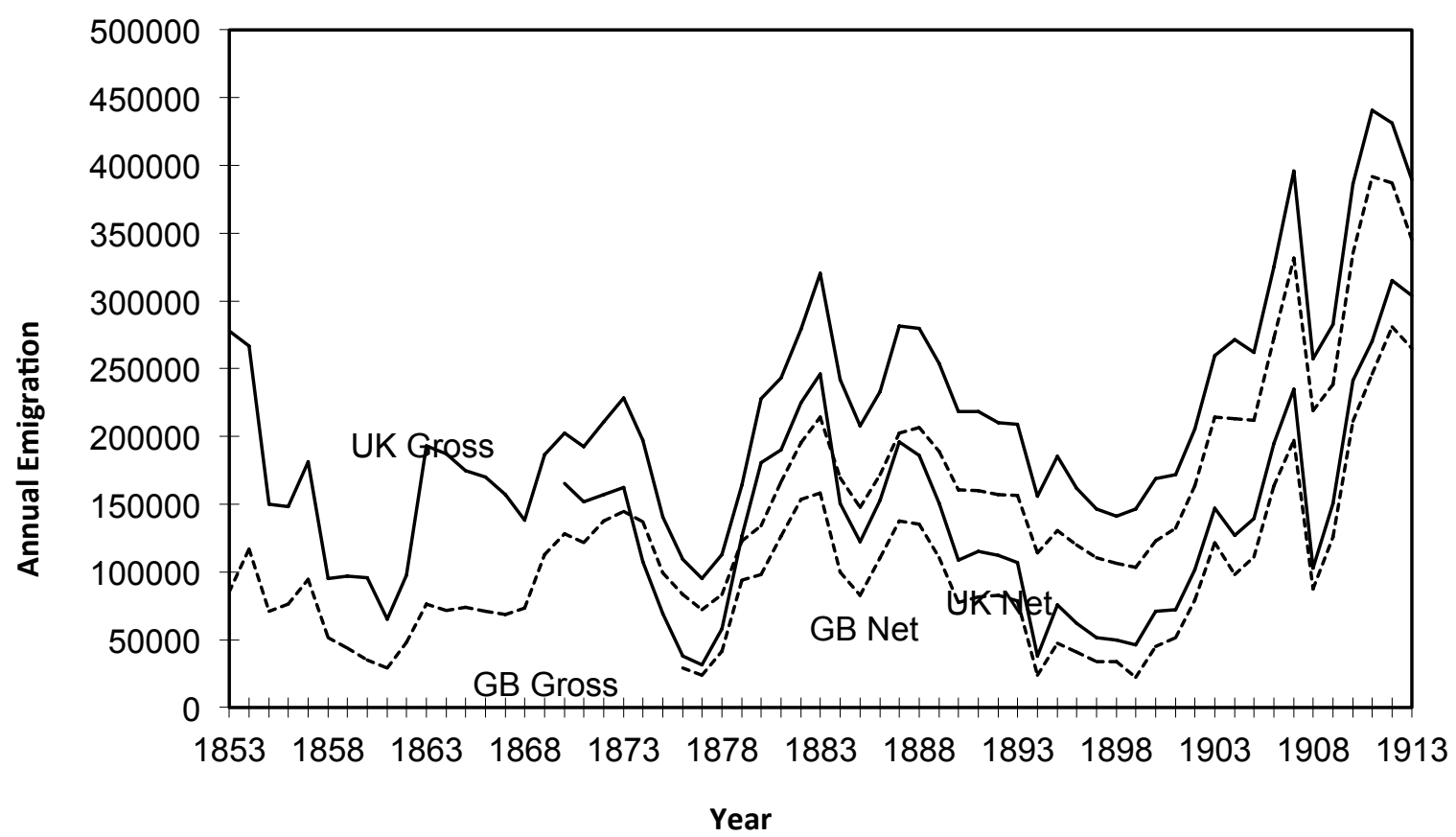

Source: Hatton (2004a)

The time profile of emigration from Britain can be seen in the passenger statistics, recorded by the Board of Trade, for ships leaving UK ports bound for non-European destinations (Figure 1). They show that there was substantial return migration; net emigration (the difference between outflows and inflows) was about 60 percent of the gross outflow. A substantial but diminishing share of the gross outflow came from Ireland (then part of the UK), especially in the aftermath of the great Irish famine of the 1840s. As Figure 1 shows emigration from British ports was significantly lower than for the UK as a whole, although this still includes some Irish migrants who departed from ports such as Liverpool. Emigrants from the UK went largely to the United States and the British Dominions. Between 1870 and 191355 percent of UK emigrants went to the United States while 20 percent went to Canada and 13 percent went to Australia or New Zealand. Most of the remainder went to Cape Colony and Natal (now parts of South Africa) and to a few places in South America and Asia.

\footnotetext{
${ }^{4}$ Erickson (1994) provides a detailed account of the occupations of English emigrants in the 1940s and the 1880 s based on information from ship's manifests, as well as an account of their experiences based on the letters that emigrants sent to their relatives back at home.
} 
After the turn of the century the share going to Canada increased steeply in response to rapid growth led by westward expansion. And in a portent of what was to come, emigration to Australia rose steeply in 1910-13 as generous immigration subsidies were introduced.

As Figure 1 shows there were large variations in emigration (both gross and net) that seem to correspond to the business cycle. A number of observers have analysed these movements as reflecting the shifting balance between 'push' forces at home and 'pull' forces abroad. They have often found that the key influence is business cycle conditions at the destination and that other influences such as relative wages had little influence (see Gould, 1979; Baines, 1991). However, a more systematic analysis suggests that emigration from the UK was driven both by relative wages and by the probability of employment at home and abroad (Hatton, 1995). Although emigration is a long term decision, dependent on expected future trends rather than on current labour market conditions, the option to choose the timing of emigration and the possibility of return ensured that short-term fluctuations in emigration closely depended on the current unemployment levels at source and destination. But the long run trend was influenced more by the relative wage and the accumulating migrant stock.

What was the effect of emigration on the UK economy? It can be estimated that in the absence of emigration from 1871 to 1911 the labour force in 1911 would have been 16 percent higher. Calculations from a general equilibrium model suggest that real wages would have been 12 percent lower as a result (Hatton and Williamson, 1998, p. 212). Thus by reducing labour supply, emigration raised wages at home. For Ireland alone the effect would have been even greater. But there are two qualifications. One is that the 12 percent wage effect is calculated under the assumption that the capital stock in 1911 would have remained at its observed level. In the absence of emigration, it seems more likely that less foreign investment would have been undertaken and the domestic capital stock would have grown more rapidly. In that case emigration would have reduced the wage by 7 percent. $^{5}$ The second qualification is that if emigration selected the more energetic and enterprising members of each cohort then perhaps innovation and growth in Britain would have been stronger had they stayed at home.

Emigration virtually stopped during the First World War and it resumed in the interwar period at a much lower level. This is sometimes associated with the introduction of immigration quotas in the United States. But the quotas were never binding on UK immigrants and emigration to other destinations where there were no such policies also failed to recover its pre-War levels. Rather, the

\footnotetext{
${ }^{5}$ The alternative counterfactual assumes that, instead of the holding the capital stock constant at the 1911 level, we assume perfect international capital mobility by holding the rate of return on capital at its observed level, thus allowing the capital stock to adjust in response to the change in labour supply.
} 
fall in emigration reflects a decline in the number of young males, and above all, deteriorating economic conditions in destination countries, which in the 1930s led to a net inflow to the UK. These conditions were reversed after the Second World War and emigration boomed, with Australia as the most important destination. This time policy was important: financial inducements (ten-pound passages) for British and Irish emigrants to Australia lasted until the early 1970s. From around 1970 total emigration to the traditional destinations declined steeply, and for two reasons. The most important one was the abolition of preferences for British immigrants in the policies of destination countries. These include a radical revision of the US quota system that took effect in 1968, the abolition of immigration subsidies in Australia and the introduction of skill-selective points systems in Canada in 1965 and Australia in 1978. In their absence emigration would probably not have declined until the 1990s (Hatton, 2004a, p. 162). The other reason is that, from the 1970s, the relative wages for skilled workers at home increased. Thus immigration policy in the destination countries restricted unskilled emigration while changing wage incentives at home reduced the incentives for skilled emigration (Hatton, 2005).

Until the 1950s immigrants from outside the British Isles were few in number. ${ }^{6}$ The start of a new pattern of immigration was signalled by the arrival of the passenger ship Empire Windrush in 1948 carrying 493 Jamaicans intending to settle in Britain. A flow of West Indians during the 1950s was soon followed by mounting numbers from elsewhere in the so-called New Commonwealth, also including Pakistan. ${ }^{7}$ These movements were facilitated by the British Nationality Act of 1948, which gave the right of immigration to citizens of the Commonwealth. After an initial surge of immigration a succession of Acts were introduced, specifically targeted at restricting immigration from the poorer, predominantly non-white, countries of the Commonwealth. ${ }^{8}$ In 1973 the right of immigration was formally abolished for all Commonwealth citizens while on the same date $\left(1^{\text {st }}\right.$ January) Britain entered what was then the European Economic Community, providing free access to the citizens of other member states. As the European Union expanded (notably with the accession of ten countries in 2004) the policy towards non-EU immigrants became increasingly restrictive. In addition, the 1990s witnessed a surge of asylum applicants that amounted to 50,000 per annum, and which was countered by a severe and progressive tightening of the rules for gaining refugee status.

\footnotetext{
${ }^{6}$ In 1911 about 1 percent of the population was foreign born; notable among them were Germans and Russian Jews.

${ }^{7}$ The former British Dominions were labeled 'Old Commonwealth' while former African and Asian Colonies were labeled 'New Commonwealth'. Pakistan was a member of the Commonwealth from 1947 to 1972, from 1989 to 1999 and again from 2008.

${ }^{8}$ These were the Commonwealth Immigrants Acts of 1962 and 1968, the Immigration Act of 1971, and the British Nationality Act of 1981.
} 
It is worth stressing three key features of postwar UK migration that are often overlooked in popular debate. The first is that Britain's gradual transition from a country of net emigration to one of net immigration (from the mid-1980s) was in large part due to declining emigration of UK citizens and only from the late 1990s to an upward trend in immigration of foreign citizens. ${ }^{9}$ The second feature is that despite the restrictiveness of immigration policy, and the even more negative tone of the public debate about immigration, the number of foreign-born continued to increase through channels such as family reunification, refugee admissions and changes of visa status. ${ }^{10}$ The foreignborn enumerated in the census increased from 5.5 percent in 1971 to 8.4 percent in 2001 (Table 3). The third point is that is that in contrast to much of the political rhetoric, the proportion born in Africa and Asia did not exceed a half until 2001. The increase in their share was due in large part to lower rates of return migration rather than to larger gross inflows (Rendall and Ball, 2004, p. 24).

Table 3: Immigrants in Great Britain, 1951-2001

\begin{tabular}{|l|r|r|r|r|r|r|}
\hline & 1951 & 1961 & 1971 & 1981 & 1991 & 2001 \\
\hline \multicolumn{1}{|l|}{ Percentage foreign-born } & 4.0 & 4.3 & 5.5 & 6.3 & 6.8 & 8.4 \\
\hline \multicolumn{7}{|l|}{ Percentage distribution of foreign-born } \\
\hline Europe & 59.9 & 53.9 & 50.8 & 41.6 & 36.4 & 31.0 \\
\hline Irish Republic & 28.2 & 24.9 & 23.8 & 18.1 & 15.8 & 10.6 \\
\hline Other Western Europe & 15.2 & 16.9 & 17.1 & 14.4 & 14.7 & 17.2 \\
\hline Africa & 3.5 & 5.3 & 7.0 & 11.9 & 13.4 & 17.9 \\
\hline South Africa & 1.8 & 1.8 & 1.5 & 1.6 & 1.8 & 3.0 \\
\hline Asia & 10.4 & 15.1 & 22.3 & 28.4 & 31.9 & 34.4 \\
\hline India & 7.3 & 7.5 & 10.8 & 11.7 & 10.9 & 10.0 \\
\hline Pakistan and Bangladesh & 0.4 & 1.4 & 4.7 & 5.0 & 9.1 & 10.2 \\
\hline China & 0.5 & 0.4 & 0.5 & 0.5 & 0.6 & 1.1 \\
\hline Americas & 8.2 & 15.8 & 15.0 & 15.1 & 13.7 & 12.2 \\
\hline USA & 3.6 & 4.6 & 3.7 & 3.5 & 3.8 & 3.3 \\
\hline Canada & 2.9 & 2.6 & 2.2 & 1.8 & 1.7 & 1.5 \\
\hline West Indies & 0.8 & 6.1 & 7.9 & 7.0 & 5.1 & 5.5 \\
\hline Oceania & 2.6 & 2.5 & 2.7 & 2.9 & 3.2 & 3.7 \\
\hline Australia & 1.8 & 1.8 & 1.9 & 1.8 & 2.0 & 2.3 \\
\hline New Zealand & 0.7 & 0.7 & 0.7 & 0.9 & 1.1 & 1.2 \\
\hline Other & 15.4 & 7.4 & 2.1 & 0.0 & 1.3 & 0.9 \\
\hline
\end{tabular}

Sources: Census of England and Wales and Scotland, birthplaces tables. Europe includes the USSR; Irish Republic includes 'Ireland, not specified'; Western Europe is the EU-12 plus Norway and Switzerland; Turkey is included in Asia; West Indies is Jamaica, Barbados, Trinidad and Tobago and 'Other West Indies' but the classification is not consistent across censuses.

\footnotetext{
${ }^{9}$ It should be noted that there was also substantial return migration: between 1970 and 1999 the gross outflow of foreign citizens was 60 percent of the gross inflow. It is estimated that 29 percent of immigrants left within two years and 46 percent within five years (Rendall and Ball, 2004, p. 24).

${ }^{10}$ One example would be foreign students admitted on student visas who, on completing their studies, then switch to a visa status that leads to permanent residency (about one fifth of all foreign students).
} 
By 2011 the share of foreign-born had risen to 11.7 percent, two thirds of whom are of working age. What effects did this mounting immigration have on the labour market? Immigrants tend to be concentrated in metropolitan areas and above all in London which in 1991 accounted for nearly 40 percent of the foreign-born but only 10 percent of the native-born population. There is some evidence that immigration into one region tends to stimulate out-migration to other regions, thus muting the local effects on wages and employment (Hatton and Tani, 2005). Most estimates for the UK (and other countries) suggest that the overall effect on the wages and employment of nonimmigrants is modest. In part this is because of international capital mobility, as noted above. One recent study finds that immigration has small negative effects on wages in the bottom quartile of the wage distribution despite the fact that immigrants on average have higher levels of education than non-immigrants (Dustmann et al., 2008). This is because immigrants, especially recent immigrants, suffer occupational downgrading, and tend to be working in jobs and at wages that undervalue their skills. Because their productivity typically exceeds the wage that they receive, this provides a 'bonus' to non-immigrants, which is reflected in slightly higher wages for those above the median of the overall wage distribution.

\section{Rural-Urban and Regional Migration}

During the last century and a half there have been major changes in the geographical distribution of the British population, due mainly to internal migration. In his pioneering analysis Ravenstein (1885) identified a number of 'laws' governing the migration process. Examining birthplace statistics in the 1881 census he found that three quarters of the population still lived in the county in which they were born. Of those that had migrated, about half moved to adjacent counties while long distance migration was chiefly to the major centres of commerce and industry. He found that population was dispersed from rural areas and absorbed by urban areas in a process whereby those moving from hinterlands into the cities were 'replaced' by migrants from further afield. He also found that women were more migratory than men, particularly over short distances, and that urban populations were less migratory than rural populations. Subsequent research has largely supported these conclusions.

The net effect of these movements was to progressively shift the balance away from rural towards urban areas. Between 1841 and 1911 rural districts of England and Wales lost 4.5 million people through migration while the cities gained 2.65 million, colliery districts gained 0.65 million and 1.2 million emigrated (Cairncross, 1949, p. 85). The major magnets were the mining districts of Wales and the Northeast, the great industrial cities of the north, such as Manchester and Liverpool, and above all London, which alone accounted for half of the urban gain. About four fifths of the migrants were aged between 15 and 35 and most of the remainder were children (Baines, 1985 p, 104). And 
because of the higher death rates in cities (noted above) a substantial share of urban population growth was accounted for by in-migration (Williamson, 1990, p. 18).

Ravenstein's 'laws' are descriptive patterns and they raise two questions. First what were the main economic factors that determined the volume and direction of migration? And second how far did migration serve to equilibrate imbalances in labour demand between rural and urban areas and across geographic regions? The fact that migrants were young and that they moved towards expanding commercial and industrial centres suggests that labour market forces were uppermost. Migration was associated with occupational upgrading and it tended to select the more able (Long 2005). Boyer and Hatton (1997) analysed out-migration rates from 19 southern and eastern over the counties to each of six major industrial and commercial destinations over the decades from 1961-71 to $1891-1901 .^{11}$ They found that the out-migration rate was negatively related to the distance to a conurbation, and positively related to the ratio of urban to rural unskilled wage rates. The wage effect implies that a ten percent increase in the wage ratio would increase the decadal migration rate about 5 percent. One important factor was the number of previous migrants from a source county at a given destination: for every thousand of the migrant stock, a further 243 followed in the subsequent decade. As with international migration, the 'friends and relatives effect' produced strong persistence in the channels of internal migration, and for much the same reasons.

What effect did these flows have on the labour market? From the 1860s to 1913 the real wages for urban unskilled workers in the building trades were between one third and 40 percent higher those for agricultural labourers (Boyer and Hatton, 1997, p. 717, 722). The 'true' gap in living standards would be smaller than this if we take account of the disamenity value of living in Victorian cities (Williamson, 1990 p. 251). Labour demand grew faster in urban than in rural areas and thus in the absence of migration the ratio of urban to rural wages would increase. One piece of evidence demonstrates how migration to the cities, by reducing labour supply, pulled up wages in rural areas. At times of industrial depression, when unemployment in the cities was high, rural -urban migration slowed down and agricultural wages declined, just as the model of Harris and Todaro (1970) suggests. As a result of this process migration flows were large enough to prevent long run divergence in wage gaps but not large enough to eliminate them. Overall there is little evidence that labour markets were becoming more integrated before the First World War. Although there was some decline in the cross-county dispersion of agricultural wages there is no such trend in the dispersion of wages in the building or engineering trades (Boyer and Hatton, 1997, p. 727).

\footnotetext{
${ }^{11}$ The six destinations are London and the Home Counties, Lancashire and Cheshire, Yorkshire, the West Midlands, the East Midlands, and South Wales. This analysis includes only male migration because the lack of female wage data makes it difficult to determine the causes of female migration.
} 
Table 4: Geographical Distribution of Population in Great Britain, 1851-2010

\begin{tabular}{|l|r|r|r|r|r|r|r|r|r|r|}
\hline & 1851 & 1871 & 1891 & 1911 & 1931 & 1951 & 1971 & 1991 & 2001 & 2010 \\
\hline Scotland & 13.9 & 12.9 & 12.2 & 11.7 & 10.8 & 10.4 & 9.6 & 9.1 & 8.8 & 8.6 \\
\hline Wales & 5.6 & 5.4 & 5.4 & 5.9 & 5.8 & 5.3 & 5.0 & 5.1 & 5.1 & 5.0 \\
\hline North & 25.4 & 27.8 & 29.8 & 30.1 & 29.7 & 28.4 & 27.0 & 25.7 & 24.9 & 24.5 \\
\hline Midlands & 14.8 & 14.5 & 14.2 & 14.1 & 14.5 & 15.4 & 16.2 & 16.6 & 16.5 & 16.4 \\
\hline South & 40.3 & 39.3 & 38.5 & 38.3 & 39.2 & 40.4 & 42.2 & 43.5 & 44.7 & 45.4 \\
\hline Metropolitan & - & - & 40.0 & 44.0 & 45.6 & 43.2 & 38.3 & 34.0 & 33.5 & 33.5 \\
\hline Other Towns & - & - & - & 49.7 & 50.4 & 52.7 & 57.4 & 60.7 & 56.2 & 56.5 \\
\hline
\end{tabular}

Source: 1911-2010: Annual Abstract of Statistics, 2010, Table 5.5; 1851-1891 calculated from Mitchell, 1988, p. $30,33$.

Migration patterns changed after the First World War. As Table 4 shows, the gradual drift away from the south was reversed after 1911, a trend that has continued to the present. This was originally due to the decline of the great the staple industries of the nineteenth century: textiles, metals, mechanical engineering, shipbuilding and coal, which were located mainly in the North of England, Scotland and Wales. Throughout the interwar period unemployment rates in these once buoyant labour markets were two to three times as high as in those in the south. ${ }^{12}$ By comparison the new growth sectors, notably light engineering, processing trades, and above all the service sector, were largely located in the Southeast and the Midlands. In the 1930s nearly half of all new manufacturing plants were established in the Southeast, a region which in 1911 had accounted for only 22 percent of manufacturing employment (Scott, 2007, p. 95). During the interwar period there was mounting concern that migration was not proceeding fast enough to alleviate unemployment and distress in what were now dubbed the depressed areas. One reason is that the faster growing sectors recruited younger workers and women in preference to seasoned and unionised coalminers and ship builders (Heim, 1984). Despite the introduction of regional transference policies, those who did move from the depressed areas often found themselves at the back of the queue for employment in the south (Scott, 2007, p. 208-14, 227).

The proportion of the population living in towns and cities increased from a half in 1851 to three quarters by the turn of the century (Lawton 1967, p. 228). In the twentieth century the process of urbanisation slowed down and changed its character. After the Second World War the share of population in the great metropolitan areas began to decline. This reflected two forces. One was the relative decline in the concentration of factory industries and those based on proximity to raw materials such as iron and coal, mainly in the north. The other was the centrifugal process of suburbanisation as major conurbations lost population and inner and outer rings around the cities

\footnotetext{
${ }^{12}$ On the basis of trade union records, Southall (1988) finds that the engineering and building trades had somewhat higher cyclical unemployment in the north than in the south, even before the First World War.
} 
expanded. By 1971 these rings accounted for a quarter of the population (Coleman and Salt, 1992, p. 103). From the 1960s provincial cities and smaller towns grew rapidly, especially in the South (Fothergill and Gudgin, 1982, Ch 5) - a tendency that was reinforced by the imposition of green belts around the major cities and the policy of developing new towns.

Postwar census data reveal what at first sight seem to be high levels of mobility, with about ten percent of the population changing address every year. However in the early 1980s over half these moves were less than five kilometres and another quarter were less than 20 kilometres (Coleman and Salt, 1992, p 404). Most migration is now inter-urban and often reflects moves to, from, or between suburbs. The evidence suggests that migration is still influenced by differences in wages and job opportunities, as it was in the nineteenth century, but there are reasons to think that it has become less responsive to economic incentives. One is that much residential mobility is undertaken for reasons such as education or retirement. Another factor is the housing market. Some observers have argued that owner occupiers and council tenants face large fixed costs of moving, while private renters are the most mobile. ${ }^{13}$ Whereas in 191390 percent of households rented on the private market, that figure fell to half by 1951 and to less than ten percent at the end of the century (Holmans, 2000, p. 487). But the fall in residential mobility was compensated to some extent by the rise of commuting. The average distance travelled to work increased from about five miles in 1970 to nine miles in 2000 , and two thirds of all journeys were taken by car.

\section{Labour Supply}

\section{Labour force participation}

Over the last century the composition of the labour force has altered with the ageing of the population and changes in participation rates. Two important life-cycle changes are the shortening of working life, and the increase in women's participation. The proportion of those under the age of 25 engaged in market work has secularly diminished, particularly among men, as the duration of education has increased. Even more notable is the fall in participation rates at the other end of the life cycle. The share of men aged 65 and over in the labour force fell from 73 percent in 1881 to under ten percent by 1981 . That decline was associated with sectoral change and with the introduction of mandatory retirement. The postwar acceleration of this trend was also associated with growth in public and private pension provision as well as the accumulation of savings over the life cycle (Johnson, 1994). In 2001 a 20 year old male could look forward to 15.6 years of retirement

\footnotetext{
${ }^{13}$ There has been a vigorous debate on this issue; for a recent analysis and overview see Meen and Nygard (2010), especially Ch 4.
} 
as compared with only 1.8 years in 1881 . About two thirds of the difference is due to increased life expectancy and only one third to earlier retirement (Crafts, 2007, p. 26).

Table 5 reports the labour force participation rates from the census of England and Wales. This is the proportion stating that they were normally 'occupied' or (from 1961) 'economically active'. It illustrates the sharp contrast between men and women. For men the participation rate for those aged 15-64 remained almost constant at around 95 percent until 1961, after which it declined as younger men stayed longer in education and older men withdrew from the labour force before reaching 65 . By contrast the participation rate for women stayed roughly constant at just under 40 percent until the Second World War after which it rose steeply. As the last column illustrates much of this is accounted for by married women whose participation rates rose from ten percent before the Second World War to two thirds by 1991.

Table 5: Labour Force Participation Rates in England and Wales.

\begin{tabular}{|c|c|c|c|c|c|c|}
\hline & $\begin{array}{c}\text { Men of } \\
\text { Working } \\
\text { Age }\end{array}$ & $\begin{array}{c}\text { Women of } \\
\text { Working } \\
\text { Age }\end{array}$ & $\begin{array}{c}\text { Men } \\
15-64\end{array}$ & $\begin{array}{c}\text { Women } \\
15-59\end{array}$ & $\begin{array}{c}\text { Married } \\
\text { Women } \\
15-59\end{array}$ & $\begin{array}{c}\text { Percentage } \\
\text { working } \\
\text { Part time }\end{array}$ \\
\hline 1881 & 82.0 & 34.0 & & & & \\
\hline 1891 & 83.1 & 34.4 & & & & \\
\hline 1901 & 83.7 & 31.6 & 95.8 & 36.5 & 13.0 & \\
\hline 1911 & 83.8 & 32.5 & 96.2 & 38.9 & 10.6 & \\
\hline 1921 & 87.1 & 32.3 & 95.3 & 36.6 & 9.5 & \\
\hline 1931 & 90.5 & 34.2 & 96.1 & 38.2 & 11.3 & \\
\hline 1951 & 87.5 & 34.9 & 95.5 & 42.6 & 25.7 & 11.9 \\
\hline 1961 & 86.2 & 37.7 & 94.7 & 46.7 & 34.6 & 25.1 \\
\hline 1971 & 81.4 & 42.8 & 91.5 & 54.8 & 49.7 & 36.2 \\
\hline 1981 & 77.7 & 45.4 & 90.3 & 60.8 & 56.9 & 36.3 \\
\hline 1991 & 73.2 & 49.8 & 86.7 & 67.6 & 66.4 & 37.1 \\
\hline 2001 & 68.4 & 52.6 & 81.5 & 70.3 & 72.0 & 33.5 \\
\hline
\end{tabular}

Sources: Census Occupation Tables. Working age is defined as from age 10 in 1881 to 1911,12 in 1921, 14 in 1931, 15 in 1951, to 1971, 16 from 1981, with no upper age limit. For married women the 1911 figure includes widows and the 2001 figure is estimated. For 1901 and 1911 female participation in the age group 55-59 is estimated. part-time share is the number employed for less than 30 hour per week divided by the total number of economically active women.

There has been considerable debate about the rise in participation, particularly among married women. One view is that low participation rates up to the 1930s simply reflect economic choices. Faced with low wages and limited employment opportunities, and with a heavy burden of looking after children, women stayed out of the labour force. One problem with this view is that we would expect to see the participation rates of married women beginning to increase at the end of the nineteenth century as fertility declined, as household technology improved, and as wages increased. And we might also have expected to see some increase in participation rates later in life as smaller 
families matured. The other is that the work of married women was governed largely by the social norm of the male breadwinner family that developed in the nineteenth century (Horrell and Humphries, 1997) and that gradually broke down during the twentieth century as women became more emancipated. Cross sectional analysis of pre-World War II participation rates supports the latter view: it was the fact of marriage rather than the presence of children that kept women out of the labour market (Hatton and Bailey, 1993). After 1945 economic incentives mattered more: the presence of children became the key constraint and women increasingly re-entered the labour market as their children grew up. ${ }^{14}$ One important factor that made this possible was the expansion of part-time work (discussed further below). From the 1980s even this effect gradually faded as family structures became more fluid and women increasingly developed lifelong attachment to the labour market.

The rise in participation was not a uniform process. Before the First World War, and into the interwar period, women's participation rates varied widely across different localities. But those differences narrowed over the twentieth century: across 102 towns the coefficient of variation of participation rates fell by more than half between 1911 and 1971. Towns and counties with low initial participation rates typically saw large increases in participation, while those with high initial participation rates saw very little increase (Hatton, 1998). ${ }^{15}$ These trends were largely the result of demand side forces. One factor is the change in industrial structure. In 1901 four-fifths of women's employment was in a narrow range of occupations: domestic and related services, textiles and clothing. The fact that these were declining sectors is one reason why participation rates stagnated in the first half of the century. But as the industrial and occupational structure of localities and regions gradually became more diversified (and the public sector expanded) regional variations in participation rates declined. In addition, occupational segregation decreased as women entered a widening range of industries and occupations (Hakim, 1994). This was associated with a decline in the sex-typing of jobs, something that was fostered by changing social norms, by the increase in

\footnotetext{
${ }^{14}$ Martin and Roberts $(1984$, Ch 2) provide detailed account of employment histories of women interviewed in 1980, while Joshi and Hinde (1993) compare two cohorts. On the determinants of participation in the postwar period see Joshi et al. (1985) and Sprague (1988).

${ }^{15}$ To give some specific examples, the participation rate for women of working age in Leicester rose only slightly from 47 percent in 1911 to 50 percent in 1971 while over the same period that for Kingston upon Hull rose from 26 percent to 42 percent and for Wolverhampton from 31 percent to 45 percent. To take the two most extreme cases, the participation rate in Blackburn fell from 59 percent in 1911 to 45 percent in 1971 while in Rhondda Urban District it rose from 14 percent to 35 percent. Thus the gap fell from 45 to 10 percentage points.
} 
women's education (which gained them access to white-collar jobs), and in the 1970 s by equal opportunity legislation. ${ }^{16}$

\section{Working hours}

Since the late nineteenth century there has been a dramatic reduction in working hours. Before the First World War the average full time industrial worker worked around nine to ten hours a day six days a week, sometimes with a short day on Saturday. By the interwar period normal weekly working hours had fallen from 56 to 48 . In the postwar period, as the five day week became the norm, working hours drifted down. Average working hours declined to 40 in the 1960s and 36 in the early 1980s and then levelled out (Green, 2001, p. 58-9). The number of working days per year also fell, initially with the introduction of a week's vacation (often unpaid) which became two weeks after the Second World War and then three weeks by the 1990s. Overall, annual working hours fell from 2,755 in 1870 to 2,275 in 1929 and to 1,653 in 2000 (Huberman and Minns, 2007, p. 548). If we take the maximum possible working time as 12 hours per day, seven days a week, then normal working hours as a proportion of potential fell from 62 percent in 1870 to just 38 percent in 2000.

These trends were common to other developed countries and the obvious question is what caused them. Higher wages have allowed individuals and households to spend less time working and to have more leisure. In terms of labour supply theory, the income effect has dominated the substitution effect. Examining data for 14 countries Huberman and Minns (2007) find that rising wages was the most important factor, helped also by the shift away from agriculture. However for Britain there were discrete steps in the fall in working hours, notably around 1870 and in 1919 . The trade union-led movement for the eight hour day gathered momentum at the turn of the century but a sudden change was triggered by First World War and the immediate postwar boom (Broadberry, 1990). Following a smaller decline in hours in 1947-8, strong growth in wages and very low unemployment led to persistent pressure for reduced working hours, which this time occurred more gradually. ${ }^{17}$

It is worth distinguishing between normal working hours and hours actually worked. As normal working hours declined, overtime working increased; by the 1980s and 1990s overtime averaged 3-4 hours per week (Hart, 2004, p. 13). On the other hand short-time and irregular working decreased. Before 1914 workers were often put on short-time working at times of recession such as in the late

\footnotetext{
${ }^{16}$ The Equal Pay Act and the Sex Discrimination Act both came into effect at the end of 1975. Zabalza and Tzannatos (1985) found that this led to a 19 percent increase in pay relative to men, and that the otherwise negative effect on employment was compensated by an outward shift in the labour demand curve.

${ }^{17}$ See Employment Outlook 1998, Ch 5. Working Hours: Latest Trends and Policy Initiative
} 
1870s and the mid-1890s, notably in textile manufacturing and coal mining. Many workers also faced intermittent employment either due to seasonality as in agriculture or due to casual employment (hiring by the day) as on the docks and in the building trades (Beveridge, 1931, pp. 77102). These features were still present in the interwar period although they were overshadowed by the numbers who were wholly unemployed. ${ }^{18}$ Then as now, in times of recession, the burden of unemployment fell disproportionately on the least skilled workers (Thomas, 1988, p. 123). For these workers, total employment over the lifetime was, and is, much lower than standard working hours would suggest. ${ }^{19}$

It is also important to note the upward trend in part-time working, particularly among women. The 1951 census was the first to ask about part-time work (defined as less than 30 hours per week). In 195112 percent of occupied women were working part-time (Table 5). ${ }^{20}$ By 1991 this proportion had risen to 37 percent. As a result of the rise in part time work the share of women in the total labour input increased by less than their share of the number of workers. Thus women's share of the labour force increased from 31 percent in 1891 to 43 percent in 1991 but their full time equivalent share increased only to 39 percent (Hakim, 1994, p. 440). Since the 1990s there has been a widening spread of working hours and conditions among both men and women. Part time employment grew more slowly and spread among men, as did temporary employment especially for those aged 16-24. At the other end of the spectrum more than a half of employed men and a fifth of women worked a normal week in excess of 40 hours in 2002 (Bishop, 2004, p. 118). There is also evidence of increasing intensity of effort especially among those working the longest hours (Green 2001; Gallie, 2000).

\section{Human Capital}

\section{Education}

One of the most striking features of change in the labour force is the growth of human capital. Despite Britain's early industrialisation, up to the mid-nineteenth century formal education was strictly limited. In response to social pressures, Forster's Education Act of 1870 prescribed universal elementary education for those aged 5-12. This involved the creation of local School Boards where

\footnotetext{
${ }^{18}$ Among those counted by the labour exchanges as unemployed about a fifth were on temporary layoff and a further five percent were listed as 'casuals' (Hatton, 2004b, p. 351-2).

${ }^{19}$ In the 1970s Nickell (1979, p. S124) estimated that time lost in unemployment for a worker with 9 years of education was about three times as high as for a worker with 14 years of education.

${ }^{20}$ It has sometimes been suggested women's work was under-recorded in the first half of the twentieth century largely because of the failure to record part-time work. Comparison with other sources suggests that part-time work was not very common and that participation is not underestimated in the census. (Hatton and Bailey, 2001, p. 103)
} 
the existing (voluntary) provision was deemed inadequate. Attendance was made compulsory up to the age of ten in 1880 and fees were abolished in 1891. An Act of 1902 created Local Education Authorities and founded a national system of secondary education (established earlier in Scotland). This was expanded by the 1918 Education Act which also raised the school leaving age from 12 to 14 (from 1921). In the late nineteenth century, elementary education consisted of reading writing and arithmetic (referred to as the three R's) for which there were seven different levels (or standards). The expansion of secondary schools saw a widening of the curriculum to include science and languages and in some areas vocational schools were established specialising in industrial or commercial education. The effect of this expansion of the public school system was to virtually eliminate illiteracy by 1914 . The average number of years of education increased from just three years for the cohort born around 1860 to about eight years for the cohort born around the turn of the century and nine years by the 1930s. But access to secondary education was largely restricted to those with middle class backgrounds and only about 15 percent of each cohort continued beyond the age of 14 (Smith, 2000, p. 194),

Secondary education was reorganised in the late 1940s into three types of schools: grammar schools, secondary modern schools and secondary technical schools and raised the school leaving age to $15 .{ }^{21}$ Selection at age 11 from what were now called primary schools into grammar schools was based on passing a general examination, the eleven-plus. About a quarter progressed to grammar school with most of the rest going to secondary moderns. From the 1960s the tripartite system was replaced by comprehensive schools in some parts of the country but not in others. ${ }^{22}$ In 1972 the school leaving age was raised from 15 to 16 , imposing a minimum of ten years of education and by the 1980s only ten percent left school with no qualification as compared with two thirds in the 1930s. The public examinations, ' $O$ ' Level (later GCSE) and ' $A$ ' level formed the progression into further and higher education; those attaining three A levels rising from 6 percent in 1961 to 16 percent in 1991.

Technical education is often seen as the missing element in the British education system and sometimes as a key factor in Britain's industrial decline relative to other countries. Before the First

\footnotetext{
${ }^{21}$ These reforms followed (but were not prescribed by) the 1944 Education Act (the Butler Act). Although they are often seen as radical reforms, the key elements were foreshadowed in a series of reports published during the interwar period, notably the 1926 Hadow Report (for the break at age 11) and the Spens Report of 1938 (for the tripartite secondary system) (see Harris 2004, pp. 270-8). Selection at the age of eleven was supported by educationalists like Sir Cyril Burt who were influenced by the eugenics movement and who believed that an individual's innate (and largely inherited) intelligence could be identified by that age. The comprehensive system grew as these views went out of fashion.

${ }^{22}$ Grammar Schools revived after 1988 when it became possible for schools to opt out of local authority control. By 199720 percent of secondary age pupils were attending grant maintained schools (Smith, 2000, p. 199)
} 
World War a few technical schools offered occupation-specific training and from the turn of the century this was expanded with Trade Schools and Junior Technical Schools, but this stream never became a central component of secondary education. For manual workers most skills were learned on the job; for craft occupations this was through the apprenticeship system. Apprenticeships involved learning a trade on the factory or workshop floor for a period of seven years, falling to five by the 1960s. Those having served an apprenticeship became recognised craftsmen such as carpenters, fitters, boilermakers, compositors and bookbinders. Under the leadership of the City and Guilds of London Institute, founded in 1879 , on-the-job training was supplemented with theoretical instruction and formal certification. The number attending evening institute courses increased from 40,000 in 1870 to over 200,000 by the turn of the century (Floud, 1982, p. 170). Apprentices formed 4.2 percent of the (male) industrial workforce in 1906, 5.0 percent in 1925, falling to 3.2 percent in 1951 (Broadberry, 2004, p. 64).

The apprenticeship system came under severe pressure in the 1960s. It was criticised for the poor quality and narrow scope of the training provided and for the length of time that it took. ${ }^{23}$ Apprenticeships increasingly included some formal daytime college instruction. This was taken a step further with the Industrial Training Act of 1964 whereby training was financed by a levy on employers. In the 1970 s and 1980 s a series of initiatives were introduced to provide an additional element of subsidised training, largely as a response to rising youth unemployment. The most prominent of these was the Youth Training Scheme, initiated in 1983 and continued in various different forms. A system of national vocational qualifications (NVQs) was introduced in 1986 to codify qualifications and enhance formal training (with further upgrading in 1992). Despite these initiatives the number of apprentices and trainees in manufacturing fell from 3.0 percent of the workforce in manufacturing in 1964 to only 1.1 percent in 1990 (Gospel, 1995, p. 37). A new system of three-year apprenticeships linked to formal qualifications was introduced in 1995 but, although there has been some increase in the numbers, it has not become a comprehensive system of vocational training like that of Germany or Denmark.

By contrast the higher education system expanded rapidly. The proportion of each age cohort attending university increased from just one percent of the age group in 1900 to 8 percent in 1963. In that year the Robbins Report established the principle of access to higher education for all who were qualified for it by ability and attainment. This involved widening access through the expansion

\footnotetext{
${ }^{23}$ There is much misunderstanding about apprenticeship, which is the acquisition of general human capital (i.e. transferable skills) in the private sector. For this to be worthwhile for the employer the initial period, when the value of the apprentice's output is less than the wage paid, must be balanced by a subsequent period when the value of output exceeds the wage. In the latter stages the apprentice could command a higher wage at another firm and so a contract of indenture is necessary to ensure that the full term is served.
} 
of existing universities and the establishment of new universities and polytechnics. In consequence, the number in full-time higher education doubled between 1963 and 1971, and it doubled again in the following twenty years. In 1992 the polytechnics and higher education colleges were upgraded to university status in order to confer parity of esteem. Participation in university-level study increased from one fifth of the age cohort in 1991 to a third in 2001, exceeding two fifths a decade later. Three key features of this expansion are worth noting. One is the relative growth of professional subjects such as business studies, accountancy and law relative to science and humanities. The second is the growing participation of women who now form more than half of those in higher education as compared with a quarter in the early 1960s. The third feature is that, although participation rates of those from lower socioeconomic backgrounds has grown rapidly, the distribution of university students is still strongly skewed towards those with middle- and uppermiddle class backgrounds.

\section{Skills and occupations}

How well have the changing workforce skills fitted the demands of the British labour market? As in other developed economies there has been a secular increase in the demand for human capital. This has resulted from structural change in favour of high-skill sectors as well as skill-biased technical change within each sector of the economy. It has been suggested that the late nineteenth century was a time when the growth of human capital caught up with the growth in demand for skills that was originally unleashed by the industrial revolution (Williamson, 1985). The twentieth century saw continuing relative decline in the demand for physical strength as jobs involving hauling, lifting and digging became more mechanised, while the demand for more advanced manual skills also declined. But the most important feature is the growth of white collar jobs involving higher levels of literacy and numeracy as well as specialised knowledge associated with scientific and technical advances. As Table 6 shows, the share of manual workers in the labour force fell by half between 1911 and 1991 while the shares of clerical, supervisory, managerial and professional workers grew by factors of between three and five. It is notable that this trend quickened after 1971.

Much of this long run evolution was due to the increase in the share of services in the economy and the decline in sectors such as agriculture, mining, manufacturing and construction. These production sectors employ a much lower ratio of white-collar to blue collar workers and it is estimated that the growth of services accounts for a third of the overall rise in white collar jobs in the half century after 1950 (Newell 2007, p. 38). There was also radical change within these broad sectors. Among the most important in the service sector was the shift away from domestic service and other menial occupations towards office-based jobs. 
Table 6: Major Occupational Groups in Great Britain, 1911-1991

\begin{tabular}{|l|r|r|r|r|r|}
\hline & \multicolumn{1}{|l|}{1911} & \multicolumn{1}{|l|}{1931} & \multicolumn{1}{l|}{1951} & \multicolumn{1}{l|}{1991} \\
\hline Employers \& proprietors & 6.7 & 6.7 & 5.0 & 4.2 & 3.3 \\
\hline Non-manual & 18.7 & 23.0 & 30.8 & 41.1 & 59.1 \\
\hline Managers and administrators & 3.4 & 3.7 & 5.5 & 6.8 & 15.1 \\
\hline Higher professionals & 1.0 & 1.1 & 1.9 & 3.3 & 5.3 \\
\hline Lower prof. and technicians & 3.1 & 3.5 & 4.7 & 7.7 & 13.9 \\
\hline Foremen and supervisors & 1.3 & 1.5 & 2.6 & 3.9 & 3.8 \\
\hline Clerical and related & 4.5 & 6.7 & 10.4 & 13.9 & 15.4 \\
\hline Sales persons & 5.4 & 6.5 & 5.7 & 5.5 & 5.6 \\
\hline Manual workers & 74.6 & 70.3 & 64.2 & 54.7 & 37.7 \\
\hline Skilled & 30.6 & 27.6 & 24.9 & 21.6 & 14.4 \\
\hline Semi-Skilled & 34.4 & 28.8 & 27.2 & 20.6 & 17.6 \\
\hline Unskilled & 9.6 & 14.8 & 12.0 & 12.5 & 5.7 \\
\hline
\end{tabular}

Source: Gallie (2000, p. 288).

How well did the supply of skills keep up with demand? According to Sanderson (2007) they were well-matched at the turn of the twentieth century, as the hierarchy of schooling meshed well with the different occupational strata. In the interwar period and into the early postwar years technical and vocational education probably expanded too slowly even though the demand for such training grew modestly. And while four fifths of pupils did not progress beyond elementary school in the interwar period, the additional years of schooling provided the basics of numeracy and literacy for lower clerical and supervisory jobs. This was especially important for women as it enabled them to move in increasing numbers into occupations such as clerks, shop assistants, teachers and nurses. These new openings compensated for the decline in the traditional female trades (noted above) and it the underpinned the postwar rise in women's labour market participation. ${ }^{24}$

It has long been believed that social mobility in Britain is relatively low and that a person's income and occupational attainment is largely determined by the social class of his or her parents. If so then much talent may have been be wasted due to the constraints of the class system. Evidence from nineteenth century marriage registers indicates that 62 percent of sons were in the same social class as their father and 40 percent were in the same occupational group (Miles 1999, pp. 23, 68). Linking fathers and sons across censuses Ferrie and Long (2007) found that occupational mobility was lower in Britain than in the United States but that this gap narrowed up to the 1970s. A principal reason was the widening access to primary and secondary education which came earlier in the US than in Britain. Education provided a means of ascending the occupational ladder but the higher rungs remained inaccessible to most. In the interwar and early postwar periods the professions and other

\footnotetext{
${ }^{24}$ The generational effect is reflected in the ages of women in different occupations. In 195071 percent of clerks and typists were under 35 as compared with only 31 percent of those engaged in domestic and personal service.
} 
elite occupations were still filled mostly by men from private schools, often via the older universities (Sanderson, 2007). But while the expansion of schooling up to the 1950 s tended to increase intergenerational mobility, the more recent growth of higher education has tended to reduce it. For the population as a whole intergenerational income mobility declined from the 1970s as middle class families took advantage of expanding opportunities for post-compulsory education (Blanden et al., 2005).

Table 7: Annualised Rates of Return to Different Qualifications, 2000-4

\begin{tabular}{|l|l|l|l|}
\hline Academic Level & Qualification & Men & Women \\
\hline 3 & 2+ A Levels & 7.1 & 6.7 \\
\hline 4 & First Degree & 7.1 & 7.2 \\
\hline 5 & Higher degree & 6.4 & 6.7 \\
\hline 3 & ONC/OND & 4.6 & 2.6 \\
\hline 4 & HNC/HND & 8.5 & 7.7 \\
\hline 5 & Other Degree/CA & 7.4 & 9.5 \\
\hline
\end{tabular}

Source: Powdthavee and Vignoles (2006), p. 13.

The explosion of further and higher education from the 1960s suggests that the supply of educational capital, particularly university degrees, may have run ahead of the demand for graduates. If so then this should be manifested by a decline in the graduate wage premium. Yet between 1980 and 2004 the graduate wage premium (over all non-graduates) increased from 48 percent to 64 percent, despite the share of graduates in the labour force rising from 5 percent to 21 percent (Machin and Vignoles, 2005). Thus, if anything, demand grew even faster than supply. Table 7 shows the incremental rate of return for different academic qualifications at about 7 percent per year of study: substantial but not spectacular. However the wage returns to different subjects varied widely with the highest returns for subjects such as business economics and law and the lower returns for arts and humanities. The evidence also suggests that higher technical qualifications yielded solid returns with level 3 vocational qualifications yielding rather less. Here too there is wide variation by sector. Indeed it has been found that the returns to NVQ2 qualifications are negligible unless undertaken together with and apprenticeship (Powdthavee and Vignoles, 2006, p. 13). Thus policies aimed at providing basic vocational skills to those who would otherwise be unskilled yield low wage returns although they may raise the probability of employment.

\section{Conclusion}

Since the late nineteenth century the British population has passed through a number of transitions which have gradually altered its size and structure. The population has increased by a factor of three, fertility and mortality rates have declined, and the population has aged as life expectancy has increased. Over the twentieth century Britain has been transformed from a country of emigration to 
a country of immigration, although the economic effects have been relatively modest. More important are the trends in urbanisation and regional migration, largely in response to the evolving structure of the economy. At the same time the working lifetime for full time workers has decreased through declines in working hours as well as later entry and earlier exit from the labour force. Against this trend the lifetime participation of partnered women has increased sharply since the Second World War. Most dramatic of all has been the growth of education, first of primary and secondary education, then of further and higher education, which has transformed the labour force and society has a whole. The key message from this chapter is that these demographic trends have been intimately connected in myriad ways with the evolution of the economy. 


\section{References}

Baines, D. E. (1985), Migration in a Mature Economy, Cambridge: Cambridge University Press.

Baines, D. E. (1991), Emigration from Europe, 1815-1930, London Macmillan.

Barnes, G. A. and Guinnane, T. W. (2011), "Social Class and the Fertility Transition: A Critical Comment on the Statistical Results Reported in Simon Szreter's Fertility, Class and Gender in Britain," Economic History Review, (forthcoming).

Beier, L. M. (2008), For Their Own Good: The Transformation of English Working-Class Health Culture, 1880-1970, Columbus OH: Ohio State University Press.

Bell, F. and Millward, R. (1998), "Public Health Expenditures and Mortality in England and Wales, 1870-1914," Continuity and Change, 13, pp. 221-249.

Beveridge, W. H. (1931), Unemployment: A Problem of Industry (1909 and 1930), London: Longmans Green.

Bishop, K. (2004), "Working Time Patterns in the UK, France, Denmark and Sweden," Labour Market Trends, March, pp. 113-122.

Blanden, J., Goodman, A., Gregg, P. and Machin, S. (2005), "Changes in Intergenerational Income Mobility in Britain," in M. Corak (ed.), Generational Income Mobility in North America and Europe, Cambridge, MA: Cambridge University Press.

Booth, A. L. and Kee, H-J. (2009), "Birth Order Matters: The Effect of Family Size and Birth Order on Educational Attainment," Journal of Population Economics, 22, pp. 367-397.

Boyer, G. R. and Hatton, T. J. (1997), "Migration and Labour Market Integration in Late NineteenthCentury England and Wales," Economic History Review, 50, pp. 697-734.

Broadberry, S. N. (1990), "The Emergence of Mass Unemployment: Explaining Macroeconomic Trends in Britain during the Trans-World War I Period", Economic History Review, 43, pp. 271-282.

Broadberry, S. N. (2004), "Human Capital and Skills," in R. C. Floud and P. A. Johnson (eds.), The Cambridge Economic History of Britain, Vol. 2, Cambridge: Cambridge University Press.

Cairncross, A. K. (1949), “Internal Migration in Victorian England', Manchester School, 17, pp. 67-87.

Crafts, N. F. R. (2007) "Living Standards" in N. Crafts, I. Gazeley and A. Newell (eds.), Work and Pay in 20th Century Britain, Oxford: Oxford University Press.

Dustmann, C., Frattini, T. and Preston, I. (2008), "The Effect of Immigration along the Distribution of Wages," University College, London, CReAM Discussion Paper 03/08 (forthcoming, Review of Economic Studies).

Erickson, C. (1994), Leaving England: Essays on British Emigration in the Nineteenth Century, London: Cornell University Press.

Ermisch, J. F. (2008), "The New Dynamics of Family Formation and the Explosion of Childbearing Outside Marriage" in J. Scott, S. Dex and H. Joshi (eds.), Women and Employment: Changing Lives and New Challenges, Cheltenham: Edward Elgar. 
Ferrie, J. and Long, J. (2007), "The Path to Convergence: Intergenerational Occupational Mobility in Britain and the US in Three Eras," Economic Journal, 117, pp. C61-C71.

Fitzpatrick, R. and Chandola, T. (2000), "Health," in A. H. Halsey and J. Webb (eds.), Twentieth Century British Social Trends, London: Macmillan.

Floud, R. C. (1982), “Technical Education and Economic Performance: Britain, 1850-1914," Albion, 14, pp. 153-171.

Floud, R., Fogel, R., Harris, B. and Hong, S. C. (2011), The Changing Body: Health, Nutrition and Human Development in the Western World since 1700, Cambridge: Cambridge University Press.

Fothergill, S. and Gudgin, G. (1982), Unequal Growth: Urban and Regional Employment Change in the $U K$, London: Heinemann.

Frijters, P., Hatton, T., Martin, R.M., Shields, M.A. (2010), "Childhood Economic Conditions and Length of Life: Evidence from the UK Boyd Orr Cohort, 1937-2005," Journal of Health Economics, 29, pp. 39-47.

Gallie, D. (2000), "The Labour Force," in A. H. Halsey and J. Webb (eds.), Twentieth Century British Social Trends, London: Macmillan.

Galor, O. and Weil, D. (1999), "From Malthusian Stagnation to Modern Growth," American Economic Review, 89 (Papers and Proceedings), pp.150-154.

Garrett, E., Reid, A., Schürer, K. and Szreter, S. (2001), Changing Family Size in England and Wales: Place, Class and Demography, 1891-1911. Cambridge: Cambridge University Press.

Gospel, H. F. (1995), "The Decline of Apprenticeship Training in Britain," Industrial Relations Journal, 26 , pp. $32-44$

Gould, J. D. (1979), “European Inter-Continental Emigration: Patterns and Causes," Journal of European Economic History, 8, pp. 593-679.

Green, F. (2001), “It's Been A Hard Day's Night: The Concentration and Intensification of Work in Late Twentieth-Century Britain," British Journal of Industrial Relations, 39, pp. 53-80.

Guha, S. (1994), "The Importance of Social Intervention in England's Mortality Decline: The Evidence Reviewed," Social History of Medicine, 7, pp. 89-113.

Harris, B. (1995), The Health of the Schoolchild: A history of the School Medical Service in England and Wales, Buckingham: Open University Press.

Harris, B, (2004), The Origins of the British Welfare State: Social Welfare in England and Wales, 18001945, Basingstoke: Palgrave.

Harris, J. and Todaro, M. P. (1970), “Migration, Unemployment, and Development: a Two-sector Analysis', American Economic Review, 60, pp. 125-42.

Hakim, C. (1994), "A Century of Change in Occupational Segregation 1891-1991," Journal of Historical Sociology, 7, pp. 435-454. 
Hanlon, P., Lawder, R. S., Buchanan, D., Redpath, A., Walsh, D., Wood, R., Bain, M., Brewster, D. H., and Chalmers, J. (2005), "Why is Mortality Higher in Scotland than in England and Wales? Decreasing Influence of Socioeconomic Deprivation between 1981 and 2001 Supports the Existence of a 'Scottish Effect'" Journal of Public Health, 27, pp. 199-204

Hart, R. A. (2004), The Economics of Overtime, Cambridge: Cambridge University Press.

Hatton, T. J. (1995), "A Model of U.K. Emigration, 1870-1913," Review of Economics and Statistics, 77, pp. 407-15.

Hatton, T. J. (1998), “Women's Work in Britain, 1911-1971: A Regional Perspective," University of Essex: Unpublished paper.

Hatton, T. J. (2004a), "Emigration from the UK, 1870-1913 and 1950-1998," European Review of Economic History, 8, pp. 149-169.

Hatton, T. J. (2004b), “Unemployment and the Labour Market, 1870-1939," in R. C. Floud and P. A. Johnson (eds.), The Cambridge Economic History of Modern Britain, Vol 2, Cambridge: Cambridge University Press.

Hatton, T. J. (2005), “Explaining Trends in UK Immigration," Journal of Population Economics, 18, pp. 719-740.

Hatton, T. J. and Bailey, R. E. (2001), "Women's Work in Census and Survey, 1911-1931," Economic History Review, 54, pp. 87-107.

Hatton, T. J. and Bailey, R. E. (1993), “Household Labour Supply and Women's Work in Interwar Britain," Explorations in Economic History, 30, pp. 229-256.

Hatton, T. J. and Martin, R. M. (2010), "Fertility Decline and the Heights of Children in Britain, 18861938', Explorations in Economic History, 47, pp. 505-519.

Hatton, T. J. and Tani, M. (2005), "Immigration and Inter-Regional Mobility in the UK, 1982-2000," Economic Journal, 115, pp. F342-F358

Hatton, T. J. and Williamson, J. G. (1998), The Age of Mass Migration: Causes and Economic Impact, New York: Oxford University Press.

Hatton, T. J. and Williamson, J. G. (2005), Global Migration and the World Economy: Two Centuries of Policy and Performance, Cambridge Mass: MIT Press.

Heim, C. (1984), "Structural Transformation and the Demand for New Labor in Advanced Economies: Interwar Britain," Journal of Economic History, 44, pp. 585-595.

Holmans, A. (2000) "Housing," in A. H. Halsey and J. Webb (eds.), Twentieth Century British Social Trends, London: Macmillan.

Horrell, S. and Humphries, J. (1997), "The Origins and Expansion of the Male Breadwinner Family: The Case of Nineteenth-Century Britain," International Review of Social History, 42, pp 25-64

Huberman, M. and Minns, C. (2007), "The Times they are not Changin': Days and Hours of Work in Old and New Worlds, 1870-2000," Explorations in Economic History, 44, 538-567. 
lacovou, M. (2008), "Family Size, Birth Order and Educational Attainment," Marriage and Family Review, 42, pp. 35-57.

Johnson, P. A. (1994), "The Employment and Retirement of Older Men in England and Wales, 18811981," Economic History Review, 47, pp. 106-128.

Joshi, H. E., Layard, R. and Owen, S. (1985), “Why Are More Women Working in Britain?” Journal of Labor Economics, 3, pp. S147-76.

Joshi, H. and Hinde, P. R. A. (1993), "Employment after Childbearing in Post-War Britain: CohortStudy Evidence on Contrasts within and across Generations, European Sociological Review, 9, pp. 203-227.

Kermack, W. O., McKendrick, A. G. and McKinley, P. L. (1934), "Death Rates in Great Britain and Sweden: Some General Regularities and their Significance," The Lancet, 31 March, pp. 698-703.

Lawton, R. (1967), "Rural Depopulation in Nineteenth-century England," in R. W. Steele and R. Lawton (eds.), Liverpool Essays in Geography: A Jubilee Collection, London: Longmans Green.

Long, J. (2005), "Rural-Urban Migration and Socioeconomic Mobility in Victorian Britain," Journal of Economic History, 65, pp. 1-35.

Machin, S. and Vignoles, A. (2006) 'Education Policy in the UK', Centre for the Economics of Education Discussion Paper CEEDP0057, London: London School of Economics.

Martin, J. and Roberts, C. (1984), Women and Employment: A Lifetime Perspective, London: HMSO.

McKeown, T. (1976), The Modern Rise of Population, London: Edward Arnold.

Meen, G. and Nygaard, A. (2010), "Housing and Regional Economic Disparities," London: Department of Communities and Local Government, Economics Paper 5.

Miles, A. (1999), Social Mobility in Nineteenth-and Early Twentieth-Century England, Basingstoke: Macmillan.

Mitchell, B. R. (1988), British Historical Statistics: Europe, Cambridge: Cambridge University Press.

Mokyr, J. (2000), "Why “More Work for Mother?" Knowledge and Household Behavior, 1870-1945," Journal of Economic History, 60, pp. 1-41.

Newell, A. (2007), "Structural Change," in N. Crafts, I. Gazeley and A. Newell (eds.), Work and Pay in 20th Century Britain, Oxford: Oxford University Press.

Nickell, S. J. (1979), “Education and Lifetime Patterns of Unemployment," Journal of Political Economy, 87, pp. S117-S131.

Office for National Statistics (2008), National Population Projections 2008-based, London HMSO.

Office for National Statistics (2011), "Health Expectancies at Birth and at Age 65 in the United Kingdom, 2007-2009," at: http://www.ons.gov.uk/ons/dcp171778_227819.pdf.

Powdthavee, N. and Vignoles, A. (2006), "Using Rate of Return Analyses to Understand Sector Skill Needs," Centre for Education Economics Discussion Paper, London School of Economics. 
Ravenstein, E. G. (1885), "The Laws of Migration," Journal of the Statistical Society of London, 48, pp. 167-235.

Rendall, M. S. and Ball, D. J. (2004), "Immigration, Emigration and the Ageing of the Overseas-born Population in the United Kingdom," Population Trends, 116, pp. 18-27.

Sanderson, M. (2007), "Education and the Labour Market" in N. Crafts, I. Gazeley and A. Newell (eds.), Work and Pay in 20th Century Britain, Oxford: Oxford University Press.

Scott, P. (2007), Triumph of the South: A Regional Economic History of Early Twentieth Century Britain, Aldershot: Ashgate.

Scott, P. (2008), "Did Owner-occupation lead to Smaller Families for Interwar Working-class Households?" Economic History Review, 61, pp. 99-124.

Smith, G. (2000), "Schools," in A. H. Halsey and J. Webb (eds.), Twentieth Century British Social Trends, London: Macmillan.

Southall, H. R. (1988), "The Origins of the Depressed Areas: Unemployment, Growth, and Regional Economic Structure in Britain before 1914', Economic History Review, 41, pp. 236-258.

Sprague, A. (1988), "Postwar Fertility and Female Labour Force Participation Rates," Economic Journal, $98,682-700$.

Szreter, S. (1988), "The Importance of Social Intervention in Britain's Mortality Decline c. 1850-1914: A Re-interpretation of the Role of Public Health," Social History of Medicine, 1, pp. 1-38.

Thomas, M. (1988), "Labour Market Structure and the Nature of Unemployment in Interwar Britain," in B. Eichengreen and T. J. Hatton (eds.), Interwar Unemployment in International Perspective, Dordrecht: Kluwer.

Van Rossum, C. T. M., Shipley, M. J., Van de Mheen, H., Grobee, D. E. and Marmot, M. G. (2000), "Employment Grade Differences in Cause Specific Mortality: A 25 year Follow up of Civil Servants from the First Whitehall Study," Journal of Epidemiology and Community Health, 54, pp.178-184.

Williamson, J. G. (1985), Did British Capitalism Breed Inequality? Boston, Mass: Allen and Unwin.

Williamson, J. G. (1990), Coping with City Growth during the British industrial Revolution, Cambridge: Cambridge University Press.

Zabalza, A. and Tzannatos, T. (1985), "The Effect of Britain's Anti-Discriminatory Legislation on Relative Pay and Employment," Economic Journal, 95, pp. 679-699. 